\title{
High androgen production by ovarian thecal interstitial cells: a mechanism for delayed ovulation in a tropical vespertilionid bat, Scotophilus heathi
}

\author{
Abhilasha and A. Krishna \\ Department of Zoology, Banaras Hindu University, Varanasi 221 005, India
}

\begin{abstract}
The steroid hormone profile of Scotophilus heathi, an Indian tropical vespertilionid bat, was studied, with special reference to the period of delayed ovulation. The results show unusually high concentrations of circulating androstenedione and testosterone during the first half of the period of delayed ovulation, whereas the concentrations of progesterone and oestradiol were relatively low during this period. Androstenedione, testosterone and oestradiol concentrations were high during the period of ovarian recrudescence (OctoberNovember). The oestradiol concentration increased, whereas androstenedione and testosterone declined significantly, before ovulation. Studies in vitro showed that the ovary secretes more androstenedione and testosterone than does the adrenal. A histological study showed that a major part of the ovary of $S$. heathi was occupied by hypertrophied interstitial cells. An immunocytochemical study showed ovarian thecal interstitial cells as the major site of high androgen synthesis in the ovary. During the period of delayed ovulation the bat ovaries thus resemble the ovaries from women with polycystic ovaries in which abnormally high androgen secretion from hypertrophied interstitial cells prevent ovulation.
\end{abstract}

\section{Introduction}

The phenomenon of delayed ovulation among the temperate zone vespertilionid bats has been known for nearly half a century (Oxberry, 1979). Studies from our laboratory have suggested that Scotophilus heathi, a tropical Indian vespertilionid bat, also exhibits this phenomenon (Krishna and Singh, 1992). One of the proposed reasons for the delay in the case of temperate zone bats is the superimposition of the period of hibernation on the season of reproduction (Oxberry, 1979; Racey, 1982). The primary aim of this study was to investigate the hormonal changes in $S$. heathi during the period of delayed ovulation. The data presented in this study indicate that high concentrations of circulating androgens may be responsible for suppression of ovulation, as found in patients with polycystic ovary syndrome (PCOS). Therefore, an attempt was made to determine whether the adrenal gland or the ovary is the major source of high androgen secretion in S. heathi and to localize the site of high androgen synthesis in the ovary.

Part of this work was presented at the 27th Annual Meeting of the Society for the Study of Reproduction, held in Ann Arbor, MI, USA.

\section{Materials and Methods}

Bats were captured live every fourth week from Banaras Hindu University Campus and adjacent areas. They were killed by decapitation as soon as they were brought to the laboratory. Blood serum was collected (pooled blood from two bats) and

Received 23 June 1995. stored at $-20^{\circ} \mathrm{C}$ until assayed for androstenedione, testosterone, oestradiol and progesterone. On the basis of the known reproductive cycle of $S$. heathi (Krishna and Singh, 1992), females were classified into the following phases:

(1) Quiescence: a reproductively inactive phase, during which the ovary does not contain any antral follicles (August-September).

(2) Recrudescence: the beginning of reproductive activity when the ovaries contain some newly formed antral follicles (October-November).

(3) Early phase of ovulatory delay during which there is a temporary arrest in reproductive activity. Ovaries contain some antral follicles (December-early January).

(4) Late phase of ovulatory delay: the ovaries contain antral follicles and mating occurs (mid-January-mid-February).

(5) Preovulatory period during which there is renewed ovarian activity and the ovaries contain large antral follicles (late February-early March).

\section{Steroid radioimmunoassay}

The circulating concentrations of steroids were measured by radioimmunoassay according to the method of Krishna and Terranova (1987). The antibody for androstenedione was obtained from J. Resko (Oregon Health Science University, Portland, $\mathrm{OR}$ ), and progesterone, oestradiol and testosterone antisera were purchased from ICN, Biomedical Inc. (Costa Mesa, CA). Radioactive androstenedione was purchased from Amersham (Bucks) and oestradiol, progesterone and testosterone from ICN Biomedical Inc. Steroids in the serum 
samples were extracted with $2 \mathrm{ml}$ diethyl ether; the ether extract was decanted, evaporated to dryness at $37^{\circ} \mathrm{C}$ and resuspended in $0.01 \mathrm{~mol}$ phosphate buffer saline-gelatin $\mathrm{ml}^{-1}$ (PBSG) for further analysis. The in vitro media were assayed without extraction.

\section{Studies in vitro}

The in vitro study was performed to determine whether the ovary or the adrenal gland is the major source of high circulating androgens in $S$. heathi. Bats collected during early December were killed as soon as they were brought to the laboratory. Their ovaries and adrenals were dissected out immediately and cleaned in Media 199 (Gibco). Ovaries (one per tube) were incubated with $1.0 \mu \mathrm{g}$ LH (NIADDK ovine LH-26) and adrenals (one per tube) with $1 \mu \mathrm{g}$ adrenocorticotrophic hormone (ACTH) (Sigma) in $1 \mathrm{ml}$ media-199 with $0.1 \%$ $(\mathrm{w} / \mathrm{v}) \mathrm{BSA}$ for $2 \mathrm{~h}$ at $37^{\circ} \mathrm{C}$. Samples of media were frozen after the incubation at $-20^{\circ} \mathrm{C}$ until assayed for androstenedione and testosterone.

\section{Histology}

Ovaries from bats were sectioned serially and stained with haematoxylin and eosin.

\section{Immunocytochemistry}

Ovaries collected during November were used for immunocytochemistry. Steroidogenic enzymes, $\mathrm{P}_{450} 17 \alpha$ hydroxylase $\left(\mathrm{P}_{450} 17 \alpha-\mathrm{OH}\right)$ and $\mathrm{P}_{450}$ side chain cleavage $\left(\mathrm{P}_{450} \mathrm{SCC}\right)$ were localized using the peroxidase antiperoxidase (PAP) technique. The primary antibodies against rat $\mathrm{P}_{450} 17 \alpha-\mathrm{OH}$ and rat $\mathrm{P}_{450}$ SCC were obtained from A. H. Payne (University of Michigan, Ann Arbor, MI) and M. J. Soares (Kansas Medical Center, Kansas City, KS), respectively. For the secondary antibody and PAP, a rabbit immunostaining kit (No. 30313324, Zymed Laboratories, San Francisco, CA) was used. Paraffin wax sections were deparaffinized in xylene, and hydrated through graded ethanol. The endogenous peroxidase activity was blocked by treating sections with $3 \%(\mathrm{v} / \mathrm{v}) \mathrm{H}_{2} \mathrm{O}_{2}$ in $10 \%(\mathrm{v} / \mathrm{v})$ methanol for $20 \mathrm{~min}$. Slides were rinsed with PBS and incubated for $30 \mathrm{~min}$ in $10 \%(\mathrm{v} / \mathrm{v})$ normal goat serum to eliminate nonspecific binding. The slides were then incubated with primary antibody (rabbit anti-rat $\mathrm{P}_{450} 17 \alpha-\mathrm{OH}, 1: 200$ dilution; rabbit anti-rat $P_{450}$ SCC, $1: 200$ dilution) in a moist chamber for $4 \mathrm{~h}$. After rinsing in PBS, sections were incubated with goat anti-rabbit $\operatorname{IgG}$ for $30 \mathrm{~min}$. Again, the slides were rinsed with PBS and incubated with rabbit PAP solution. After washing in Tris- $\mathrm{HCl}$ saline buffer $\left(0.05 \mathrm{~mol} \mathrm{l}^{-1}\right)$, the sections were developed in $0.01 \%(\mathrm{w} / \mathrm{v}) 3^{\prime}-3^{\prime}$ diaminobenzidine tetrahydrochloride and $0.01 \%(\mathrm{v} / \mathrm{v}) \mathrm{H}_{2} \mathrm{O}_{2}$ in Tris- $\mathrm{HCl}$ buffer, dehydrated and mounted in distreine pathalate xylene (DPX). All the incubations were carried out at room temperature. The control slides were incubated with buffer instead of primary antibody.

\section{Electron microscopy}

Bats $(n=3)$ collected during December were killed by perfusion fixation. One-hundred iu heparin (Liquemin 100R,
Hoffmann La Roche, Grenzach-Whylem, Germany) per $100 \mathrm{~g}$ body mass were injected i.p. under anaesthesia $(6 \mathrm{mg}$ pentobarbital per $100 \mathrm{~g}$ body mass), $15 \mathrm{~min}$ before beginning the perfusion. The thoracic and abdominal cavities were opened along the midline of the body and a blunt cannula fitted to a silicone tube was introduced into the left ventricle and slowly pushed into the ascending aorta. After fixing the cannula with one clamp, and interrupting the large cervical blood vessels with other clamps, the remaining blood circulation was rinsed by $50 \mathrm{ml}$ Ringer's solution using a perfusor. The speed of the perfusor was adjusted to $300 \mathrm{ml} \mathrm{h}^{-1}$. After rinsing, $50 \mathrm{ml}$ fixative, $1 \%(\mathrm{v} / \mathrm{v})$ glutaraldehyde, $1 \%(\mathrm{w} / \mathrm{v})$ paraformaldehyde in 0.1 mol Sorensen's buffer $1^{-1}(\mathrm{pH} \mathrm{7.4)}$, was injected. The ovaries were dissected out and trimmed pieces of ovary were postfixed in $2 \%(\mathrm{v} / \mathrm{v})$ osmium tetroxide. Tissues were embedded in Araldite.

\section{Statistical analysis}

The data were analysed by one-way analysis of variance (ANOVA) followed by Fisher's protected least significant difference and Schiffe's Test when differences were significant. Differences were considered significant when $P<0.05$. Data are expressed as means \pm SEM.

\section{Results}

\section{Circulating concentrations of steroids in relation to delayed ovulation}

Circulating concentrations of androstenedione, testosterone, oestradiol and progesterone during different stages of ovarian cycles are shown in Fig. 1. The concentration of androstenedione began to increase from quiescence and reached an unusually high peak during recrudescence. The concentration of testosterone also began to increase from quiescence and was high during recrudescence, reaching a peak during the early phase of ovulatory delay. Serum oestradiol concentration increased, whereas progesterone concentration decreased from quiescence to recrudescence. Concentrations of testosterone and androstenedione were high during the early phase of ovulatory delay, whereas oestradiol concentration fell during this phase. Serum concentration of both androstenedione and testosterone gradually declined from the early to the late phase of ovulatory delay, when mating takes place, and reached a minimum during the preovulatory phase. The oestradiol concentration increased before ovulation. Progesterone concentrations in serum were unchanged during the period from recrudescence until before ovulation.

\section{The major source of high circulating androgen}

The concentration of androstenedione and testosterone secreted in vitro by the ovary and the adrenal following stimulation with $\mathrm{LH}$ and $\mathrm{ACTH}$, respectively, are shown in Fig. 2. The ovary secreted a far larger amount of both androstenedione and testosterone compared with the adrenal. 

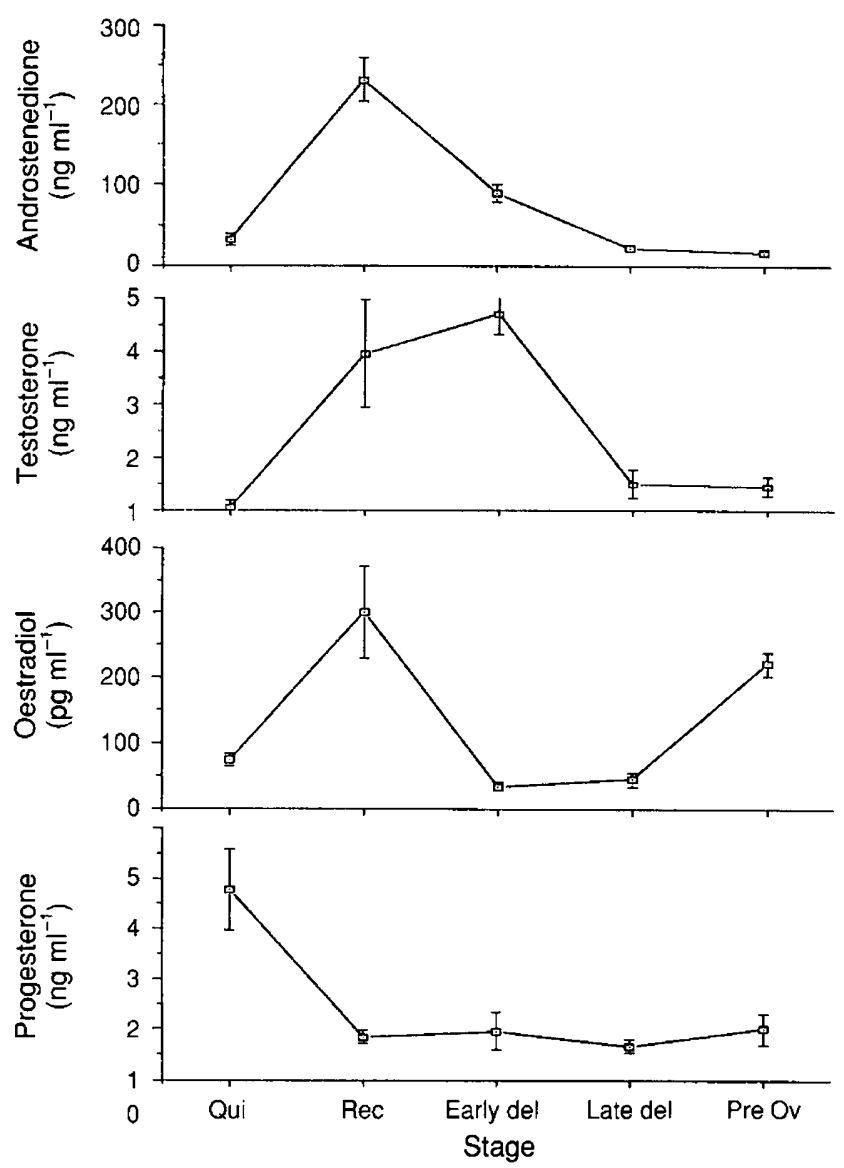

Fig. 1. Variation in serum concentrations of androstenedione, testosterone, oestradiol and progesterone in Scotophilus heathi during different reproductive stages. Values are means \pm SEM. Qui: quiescence $(n=12$; 15 August 1992); Rec: recrudescence ( $n=8 ; 3$ November 1992); Early del: early phase of ovulatory delay $(n=10 ; 7$ December 1992); Late del: late phase of ovulatory delay $(n=8 ; 8$ January 1993); Pre Ov: preovulatory period ( $n=6 ; 28$ February 1993). Values in parentheses indicate the number of bats $(n)$ used and the time of collection.

\section{The site of androgen synthesis in the ovary}

Histology. The ovary was relatively large in NovemberDecember and contained a number of follicles of different sizes, both healthy and atretic, separated by the extensive interstitial tissues. The interstitial cells were so extensive that, besides the follicles, they occupied the major part of the ovary (Fig. 3a). Interstitial cells were polygonal with comparatively smaller nuclei and a highly vacuolated cytoplasm (Fig. 3b). They were found associated with healthy as well as atretic follicles. Under the microscope, thecal cells and interstitial cells appeared similar (Fig. 3c). Ultrastructural studies on interstitial cells revealed abundant round to ovoid lipid droplets (Fig. 3d). Rod to round-shaped mitochondria were distributed between lipid droplets and constituted the second most conspicuous cytoplasmic organelle. The endoplasmic reticulum was generally agranular and ribosomes were dispersed throughout the cytoplasm.

Immunocytochemistry. Immunocytochemical localization of steroidogenic enzymes $\mathrm{P}_{450} \mathrm{SCC}$ and $\mathrm{P}_{450} 17 \alpha-\mathrm{OH}$ showed

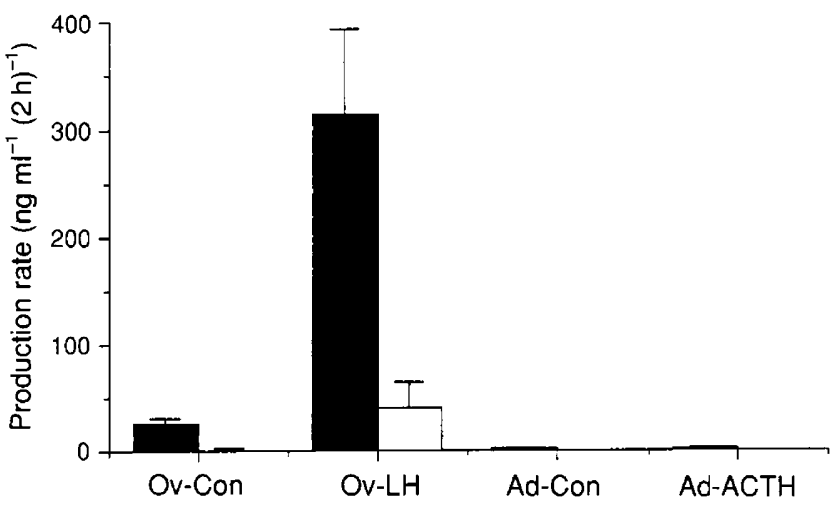

Fig. 2. Effect of LH on ovarian and $A C T H$ on adrenal androstenedione ( $\square$ ) and testosterone ( $\square$ ) production in vitro during early December (7 December 1992) in Scotophilus heathi. Values are means \pm SEM. Ov-Con: ovary control $(n=3)$; Ov-LH: ovary LH-stimulated ( $n=3$ ); Ad-Con: adrenal control $(n=4)$; Ad-ACTH: adrenal ACTH-stimulated $(n=4)$. $n$ : number of tissues incubated.

intense positive reaction, mainly in the thecal cells and interstitial cells of the ovary (Fig. 3e, f). Granulosa cells did not show any positive immunoreaction. Control slides showed no reaction.

\section{Discussion}

The phenomenon of delayed ovulation found in temperate zone vespertilionid bats is thought to be related in some way to the metabolic depression characteristic of the hibernating state (Oxberry, 1979; Racey, 1982). Although none of the tropical vespertilionids undergoes prolonged hibernation, many seem to resemble hibernating bats in having a reproductive cycle characterized by slow follicular maturation, unique specialization in the Graafian follicle and a prolonged oestrus (Dominic and Krishna, 1989). Thus, it appears that the prolonged hibernation, which characterizes temperate zone species, is not a necessary preadaptation for delayed ovulation. To our knowledge, this is the first detailed study describing the changes in circulating steroid concentrations in relation to delayed ovulation in a vespertilionid bat. The results indicate that the ovary of $S$. heathi secretes unusually large amounts of both androstenedione and testosterone during the period of recrudescence and the early phase of ovulatory delay; circulating concentrations decline to very low values during the period when mating and ovulation normally take place in this species (Krishna and Singh, 1992). Thus, it is possible that the high circulating concentrations of androstenedione and testosterone may be responsible, in part, for suppressing or delaying ovulation in S. heathi.

Female $S$. heathi in the present study displayed concentrations of circulating androstenedione that were unusually high compared with the values reported for most other mammals (Feder, 1985; Glickman et al., 1992). The concentrations of circulating testosterone were also high, but not as high as those of circulating androstenedione. To our knowledge the circulating androstenedione and testosterone concentrations of any other female bat are not known. However, whenever plasma testosterone concentrations have been 

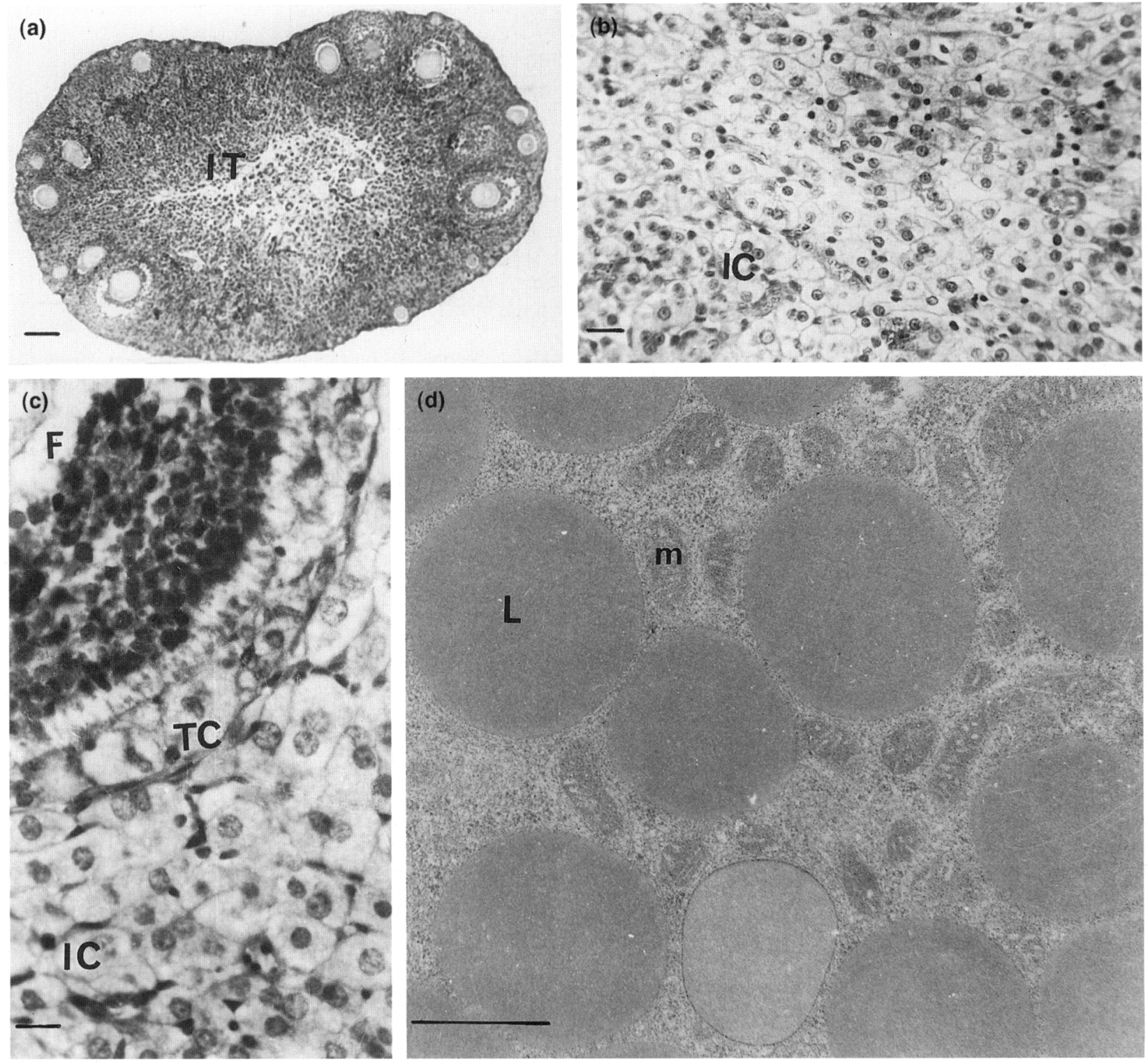

(d)

(e)

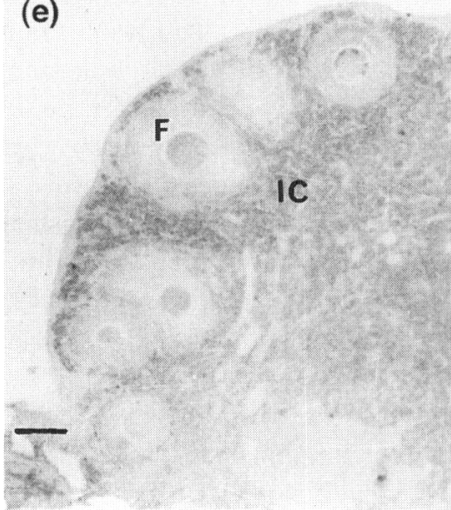

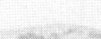

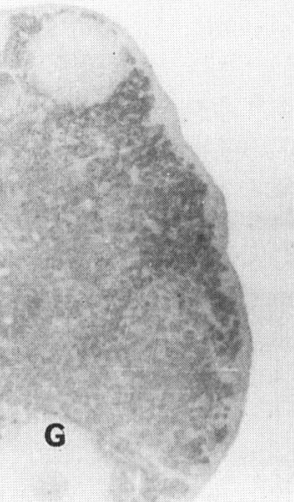

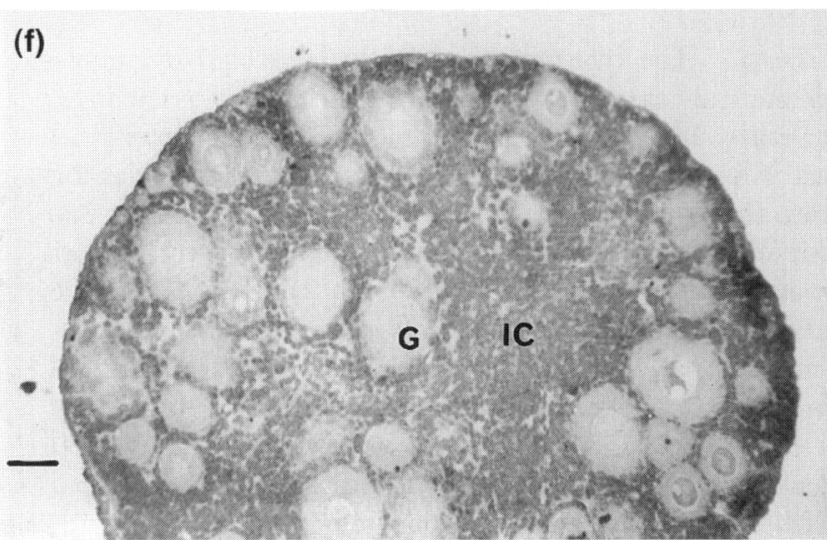

(f)

Fig. 3. (a) Cross-section of the ovary of Scotophilus heathi, showing extensive interstitial tissue (IT) and a number of growing follicles in the periphery. Scale bar represents $100 \mu \mathrm{m}$. (b) Interstitial tissue as seen under light microscope at high magnification. Interstitial cells (IC) with vacuolated cytoplasm and an irregular nucleus are seen. Scale bar represents $50 \mu \mathrm{m}$. (c) A portion of the ovary showing a part of the follicle (F). Note the similarity between thecal (TC) and interstitial cells (IC). Scale bar represents $10 \mu \mathrm{m}$. (d) Fine structure of interstitial cell, showing a large number of lipid droplets (L) of various sizes and mitochondria (m). Scale bar represents $I \mu m$. (e) Immunocytochemistry of $\mathrm{P}_{450}$ side chain cleavage in the ovary of $S$. heathi. The thecal cells and interstitial cells (IC) are immunostained. The granulosa cells (G) are negative. F: follicle. Scale bar represents $100 \mu \mathrm{m}$. (f) Immunocytochemistry of $P_{450} 17 a-O H$ in the ovary of

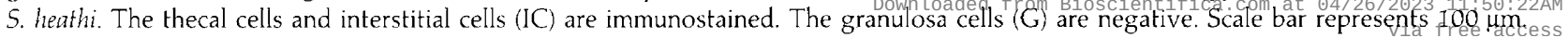


measured in male microchiropterans, the majority have been extremely high compared with those of most eutherians (Racey, 1974; Gustafson and Shemesh, 1976).

The present study in vitro indicates that the ovary is the major source of both androstenedione and testosterone in S. heathi. One of the most striking cytological features of the ovary of $S$. heathi is the dominance of the interstitial cells. Practically all of the interfollicular tissue of the ovary of $S$. heathi consisted of a mass of interstitial cells. Histologically, the thecal cells and interstitial cells looked alike and, therefore, may be called thecal-interstitial cells. Thecal-interstitial cells are generally formed owing to accumulation of thecal cells from the atretic follicle in the stroma (Guraya and Greenwald, 1968). Although such extensive development of interstitial cells has been reported in some species of bat (Kayanja and Mutere, 1975; Rasweiler, 1988; Tsvetkov and Takeva, 1988), its significance has not yet been demonstrated. Immunocytochemical localization of $\mathrm{P}_{450} \mathrm{SCC}$ and $\mathrm{P}_{450} 17 \alpha-\mathrm{OH}$ in the ovary suggests that thecal-interstitial cells are the major site of steroidogenic activity and androgen secretion. Overproduction of androgen is therefore attributed to the hypertrophied thecal-interstitial cells of the ovary in S. heathi.

The intraovarian effects of androgens are well documented in rodents and include changes in steroid production, inhibition of follicular growth and ovulation and an enhanced rate of follicular atresia (Louvet et al., 1975; Lindner et al., 1977; Azzolin and Saiduddin, 1983). Androgens have also been implicated aetiologically in the establishment of PCOS in humans (Yen, 1980). It has been shown experimentally in rats and monkeys that treatment with high concentrations of androgen results in morphological changes in the ovary, resembling those found in PCOS (Ward et al., 1978; Billiar et al., 1985; Faiman $e t$ al., 1988). Polycystic ovaries are characterized by large numbers of small antral follicles surrounded by hypertrophied thecal and interstitial cells; these cells produce large amounts of androgens which prevent the follicles from ovulating (Rosenfield et al., 1990). One of the most important consequences of PCOS is the failure to produce dominant follicles in the ovary. Similarly, in $S$. heathi thecal-interstitial cells surrounding the follicles showed intense $\mathrm{P}_{450}$ SCC and $\mathrm{P}_{450} \quad 17 \alpha-\mathrm{OH}$ activities, and thus may be secreting large amounts of androgen. Oversecretion of androgen may have inhibited follicular growth and, consequently, selection of a dominant follicle. Singh and Krishna (1992) failed to induce ovulation in this species using hCG and pregnant mares' serum gonadotrophin during the period of ovulatory delay. This study also indicates the absence of dominant or selected follicles in this species during this period. The causes of the decline in serum androgen concentrations during the preovulatory period are not known. However, further research may prove useful for developing $S$. heathi as a model to investigate the mechanism responsible for hyperandrogenism and to devise therapeutic strategies for its treatment.

The authors thank NIDDK for providing the ovine LH, A. H. Payne, M. J. Soares and J. Resko for providing $\mathrm{P}_{450} 17 \alpha$ hydroxylase, $\mathrm{P}_{450} \mathrm{SCC}$ and androstenedione antibodies, respectively. The authors gratefully acknowledge P. F. Terranova, Department of Physiology,
Kansas Medical Centre for help and advice throughout the study. This work was supported in part by UGC and CSIR, India.

\section{References}

Azzolin GC and Saiduddin S (1983) Effect of androgens on the ovarian morphology of the hypophysectomized rat Proceedings of the Society for Experimental Biology and Medicine 172 70-73

Billiar RB, Richardson D, Anderson E, Mahajan D and Little B (1985) The effect of chronic and acyclic elevation of circulating androstenedione or estrone concentration on ovarian function in the rhesus monkey Endocrinology 116 2209-2220

Dominic CJ and Krishna A (1989) Reproductive cycles of mammals: Chiroptera and Insectivora. In Reproductive Cycle of Indian Vertebrates pp 311-346 Ed. SK Saidapur. Allied Publishers Limited, New Delhi

Faiman C, Reyes FI, Dent DW, Fuller GB, Hobson WC and Thliveris JA (1988) Effect of long term testosterone exposure on ovarian function and morphology in the rhesus monkey Anatomical Record 222 245-251

Feder HH (1985) Peripheral plasma levels of gonadal steroids in adult male and adult nonpregnant female mammals. In Handbook of Behavioral Neurobiology Vol. 7 pp 299-370 Eds N Adler, D Pfaff and RW Goy. Plenum Press, New York

Glickman SE, Frank LG, Pavgi S and Licht P (1992) Hormonal correlates of masculinization in female spotted hyaenas (Crocuta casouta). I. Infancy to sexual maturity Journal of Reproduction and Fertility 95 451-462

Guraya SS and Greenwald GS (1968) A comparative histochemical study of interstitial tissue and follicular atresia in the mammalian ovary Anatomical Record 149 411-417

Gustafson AW and Shemesh M (1976) Changes in plasma testosterone levels during the annual reproductive cycle of the hibernating bat Myotis lucifugus lucifugus with a survey of plasma testosterone levels in adult male vertebrates Biology of Reproduction 15 9-24

Kayanja FIB and Mutere F (1975) The ovary of the insectivorous bat Otomops martiensseni Anatomisc Anzeiger 137 166-175

Krishna A and Singh UP (1992) Morphometric changes in the ovaries of the Indian vespertilionid bat Scotophilus heathi with reference to delayed ovulation European Archives of Biology 103 257-264

Krishna A and Terranova PF (1987) Effects of gonadotrophin surge at proestrus on steroidogenesis and gonadotrophin binding of preantral follicles in the cyclic hamster Joumal of Endocrinology 114 49-55

Lindner HR, Amsterdam A, Salomon Y, Tsafrini A, Nimrod A, Lamprecht SA, Zon $U$ and Koch $Y$ (1977) Intraovarian factors in ovulation: determinants of follicular response to gonadotrophins Journal of Reproduction and Fertility $\mathbf{5 1}$ 215-235

Louvet JP, Marmas SM, Shreiber JR and Ross GT (1975) Evidence for a role of androgen in follicular maturation Endocrinology 97 366-372

Oxberry BA (1979) Female reproductive patterns in bats Journal of Reproduction and Fertility 56 359-367

Racey PA (1974) The reproductive cycle of the male noctula bat Nyctalus noctula Journal of Reproduction and Fertility 41 169-182.

Racey PA (1982) Ecology of bat reproduction. In Ecology of the Bat pp 57-104 Ed. TH Kunz. Plenum Press, New York

Rasweiler JJ (1988) Ovarian function in the captive black mastiff bat, Molossus ater Journal of Reproduction and Fertility 82 97-111

Rosenfield RL, Barner RB, Cara JR and Lucky AW (1990) Dysregulation of cytochrome $\mathrm{P}_{450} 17 \alpha$ as the cause of polycystic ovarian syndrome Fertility and Sterility $\mathbf{5 3} 785-791$

Singh UP and Krishna A (1992) Effect of hCG and PMSG on responsiveness of ovary during period of delayed ovulation in an Indian vespertilionid bat, Scotophilus heathi Indian Journal of Experimental Biology 30 670-675

Tsvetkov T and Takeva T (1988) Changes in interstitial gland in the ovary of the bat, Rhinolophus eruale Blas: arousal from hibernation Cryobiology 25 502-507

Ward RC, Costoff A and Mahesh VB (1978) The induction of polycystic ovaries in mature cycling rats by the administration of dihydroepiandrosterone (DHA) Biology of Reproduction 18 614-662

Yen SCC (1980) The polycystic ovary syndrome Clinical Endocrinology 12 $177-208$ 